\title{
Determinants of Poverty Level in Nigeria
}

\author{
Olabode Philip Olofin ${ }^{1}$, Akintoye Victor Adejumo ${ }^{1}$ \& Kazeem Abimbola Sanusi ${ }^{1}$ \\ ${ }^{1}$ Department of Economics, Obafemi Awolowo University, Ile-Ife, Nigeria \\ Correspondence: Olabode Philip Olofin, Department of Economics, Obafemi Awolowo University, Ile-Ife, \\ Nigeria. E-mail: opolofin@oauife.edu.ng; kasanusi@oauife.edu.ng
}

Received: October 31, 2014 Accepted: November 19, 2014 Online Published: January 29, 2015

doi:10.5539/jsd.v8n1p235

URL: http://dx.doi.org/10.5539/jsd.v8n1p235

\begin{abstract}
This study uses annual data between 1990 and 2010, and employs Dynamic Ordinary Least Square (DOLS) method to examine what determines poverty level in Nigeria. Unlike many studies, we measure poverty with poverty index generated from combination of per worker agricultural value added, real per capita income and consumption per capita using principal component analysis and common measurement of poverty (i.e. per capita real income). We first remove the trend component of our dependent variables (poverty index), using Butterworth filter and then regressed them on the important variables of interest. The findings show negative relationship between political right in levels and poverty, but positive relationship was found when political right was differenced. This result was not statistically significant. Political terror was found to reduce poverty with statistically significant result in levels when per capita real income was used for poverty, and became positively related with poverty when differenced. The result was statistically significant. We found that civil liberty was positively related to poverty, but the result was not statistically significant. Democracy was noted for reducing poverty with statistically significant result, while the increase in population and poverty were positively related with statistically significant result.
\end{abstract}

Keywords: poverty, component principal analysis index, Butterworth filters, dynamic ordinary least square, Nigeria

\section{Introduction}

Economic policy stance once viewed poverty reduction as a consequence of economic growth, but development economists have long realised that this is not always true (Mahbub ul Haq, 1971; Gerald Meier, 1976). Indeed, evidences show that the view that growth automatically takes care of poverty may not be compatible with the situation in Nigeria. For instance, National Bureau of Statistics figures showed that poverty incidence worsened between 2004 and 2010, despite impressive growth record over this period. This paradox of growth in the face of poverty calls for renewed efforts on investigating what determines poverty in Nigeria. While it is true that many studies have been done on determinants of poverty in Nigeria, to the best of our knowledge, no known study has considered the variables we consider in this study as well as the methodology adopted.

Aside from the above, studies have shown that findings on the determinants of poverty were inconclusive (see Quisumbing, 2007; Rodriguez, 2011; Sawhill, 1998). Bearing in mind that poverty is multifaceted; examining its causes requires a holistic approach. Studies that focus on a particular cause of poverty level, especially in Nigeria would not only be studying the behaviour of a black cat, but the one in a black box inside a dark room, hence this study. The remainder of this paper is organized as follows. Section 2 examines the literature review, section 3 discusses and specifies our model, section 4 discusses the method, sources of data and measurement of variables, while section 5 discusses the results and presents policy recommendation.

\section{Literature Review}

Generally speaking, the literature on poverty determinants can be looked at from both the micro and macro analysis. On the micro side, it has been noted that poverty determinants at the level of households are mostly omitted in the aggregate analysis and this conceals information at the microeconomic level (Collier \& Gunning, 1999: 83; Christiaensen, Demery \& Paternostro 2003). Also, Ravallion (2001) stressed the importance of microeconomic approach in the examination of poverty determining factors in the presence of economic growth. He used household survey data from a sample of 50 countries and 120 indications of poverty change to estimate an average growth elasticity of headcount poverty at -2.5 . He concluded that this average conceals variations 
across countries and calls for more micro and country specific studies on poverty determinants in a growing economy.

Recently, literatures suggest that the key micro level determinants of poverty generally include household size, education level, household composition and size, assets owned by households, access to basic social and economic services, sector of employment, number of income earners in a household, sex and ethnicity of household head, rural versus urban location, among others. Beginning with education level, Geda et al. (2005) used household level data to examine poverty determinants in Kenya. By employing binomial and polychotomous logit models, they found that poverty status is strongly associated with the low level of education among other factors. This result is in agreement with that of Anderson et al (2005) who used multiple regressions to examine determinants of poverty in Lao PDR. Similarly, Apata et al. (2010), who examined determinants of rural poverty in Nigeria using probit model on a sample of 500 smallholder farmers, found that access to education improved probability of existing poverty. Furthermore, they found that the key role of education in poverty reduction is further underscored by evidence from farmers' exposure to workshops and seminars. Studies of Rodriguez (2011), Mexican, Eirini and Panos (2011), and the Sinnathurai and Brezinova (2011) which focused on poverty determinants in Sri Lankan estate sector, supported this result. Ibrahim and Umar (2007) also found that poverty incidence falls with the number of literate adult males and females in the household. However, Tshediso (2012) using a logistic regression method found that education level is insignificant in explaining poverty in South African female-headed households. This result is contrary to findings from other studies.

Another key poverty determinant in microeconomic literature is the set of household size, composition and number of income earners. Again, empirical evidence posits that incidence of poverty increases with household size (see for example, Geda et al;: 2005, Ibrahim and Umar, 2007 and Rodriguez, 2011). Ibrahim and Umar (2007) further found that among farming households in Nasarawa State, Nigeria, poverty incidence reduces with the number of household head income sources and with the number of household members employed outside agriculture.

Regarding asset ownership status and access to social and economic services as determinants of poverty, Apata et al. (2010) provides evidence that access to micro - credit and market as well as ownership of livestock asset significantly contributes to poverty reduction. Their study also showed that bias against women in property rights has negative consequences on poverty. Anderson et al. (2005) earlier reached a similar conclusion. They found that access to agricultural inputs is among the main determinants of poverty, measured in terms of per capita consumption in Lao PDR. They further concluded that higher poverty incidence was a feature of minority households because of their restricted access to productive resources and not because of lower efficiency in resource used. More recently, findings by Sinnathurai and Brezinova (2011) support the earlier empirical evidence that access to market and infrastructure significantly and negatively affect poverty in the real estate sector of Sri Lanka. Surprisingly, Adeyemi et al. (2009) in their assessment of determinants of poverty in Sub-Sahara Africa found that lack of access to health care service is not important as a determinant of poverty.

On the influence of location variable (rural or urban) and of sector of employment on poverty incidence, Geda et al (2005) found evidence that poverty status is strongly associated with engagement in agricultural activity. This is similar to the findings of Dawood et al. (2008) with the recommendation of productivity stimulating investment in Pakistan agricultural sector. Rodriguez (2011) also found similar evidence that being an agricultural, domestic, transportation, manufacturing (casual labour) or sales worker is positively connected with the probability of being poor. Sinnathurai and Brezinova (2011) noted that agricultural employment has a negative but insignificant effect on poverty incidence in Sri Lanka and this finding was corroborated by Ojimba (2012) who found that poverty incidence spreads more with agricultural employment.

Considering the macro analysis of poverty determinants, it has been noted that works on macroeconomic determinants of poverty are scarce (Agénor, 2005). This is despite the need to understand how microeconomic decisions on poverty alleviation can be contained within macroeconomic outcomes. Literature has shown that there exists links between macroeconomic variables and poverty. First, is the transmission from economic growth to poverty. A common consensus now is that sustained economic growth is a pre-condition for sustainable poverty reduction (Kanbur, 2001). Growth can reduce poverty through employment generation, higher labour productivity and increased real wage. However, the observation that growth only is not sufficient for poverty reduction prompted the promotion of 'pro-poor' growth policies to eradicate poverty (see for example, Epaulard (2003), Agenor (2005), Akoum (2008), Azis (2008), and Tarabini (2010)). It is therefore expected that economic growth which is characterised by lack of employment generation, high labour productivity, quality education at all levels, and manufactured export competitiveness, for instance, impact less on poverty reduction. Nevertheless, evidence abound that links growth with poverty reduction (see World Bank, 
1990). This is especially so when growth and distribution policies are sound and intertwine.

Macroeconomic instability, which may be due to exogenous shocks (natural disasters, terms of trade shocks, reversals in capital flows etc) or monetary/fiscal policy failure, is another determinant of poverty. Such instability may be associated with stagnation or declining GDP, double digit inflation rate, high public debt, huge current account deficit, among others. Macroeconomic shocks and policy failure explain poverty because they constrain the poor from using their greatest asset, labour. When low or negative output growth is its source, macroeconomic instability results in higher unemployment for the poor, hence increased poverty level.

\section{Model Specification}

Findings from studies have shown that increased terrorism may force a listening government to implement policies that will reduce poverty and that granting political right, civil liberty, democracy, and effective use of manpower (i.e. population increase) may also cause reduction in poverty rate. Following this, we specify our regression equations as:

$$
\begin{aligned}
\text { Pov } & =\mathrm{f}(\text { polright, polterror, civiliberty, democracy, popincrease }) \\
\mathrm{rpky} & =\mathrm{f}(\text { polright, } \text { polterror, civiliberty, democracy, popincrease })
\end{aligned}
$$

Where pov and rpky stand for poverty index (rpkY_bw and poverty_bw), polright is political right, polterror is political terror, civiliberty is civil liberty and popincrease is population increase.

\section{Methodology, Data Measurement and Sources}

This study considers the multifaceted nature of poverty by measuring it with index generated from combination of human development indicators (i.e. rural development measured by per worker agricultural value added, real per capita income and consumption per capita which represents access to resources needed for a decent standard of living, (see Masud \& Yoncheva, 2005; Chirino \& Melian, 2006; Morrissey, 2004) using principal component analysis as well as employing real per capita income commonly used by most studies. Other variables of interest used in the study are: political right, political terror, civil liberty, democracy and population increase. Data on agricultural value added, real per capita income, consumption per capita and population were obtained from the World dataBank (World Development Indicators (2012), while others were calculated and obtained as: (i) political terror scale based on reports by Amnesty International coded from 1-5 (see www.politicalterrorscal.org); (ii) The extent of civil liberties in a country as calculated by Freedom House. Coded from 1-7 (7 being the worst), (iii) The extent of political rights in a country as calculated by Freedom House. Coded from 1-7 (7 being the worst) and (iv) The Democracy indicator is an additive eleven-point scale (0-10) as calculated by POLITY IV.

We filter the trend component out of the series real per capita income and the other measure of poverty that serve as our dependent variables so as to obtain the stationary component of each of the series by using Butterworth filters. The graphical result is presented in figure 1 in the appendix. Unlike other filters, Butterworth filter is noted for its ability to be "maximally flat". The gain functions of these filters are as close as possible to being a flat line at 0 for the unwanted periods and a flat line at 1 for the desired periods, (see Butterworth, 1930 and Bianchi and Sorrentino, 2007, pp. 17-20). The result of the filtered trend component of our variables is presented in figure 1 below. 


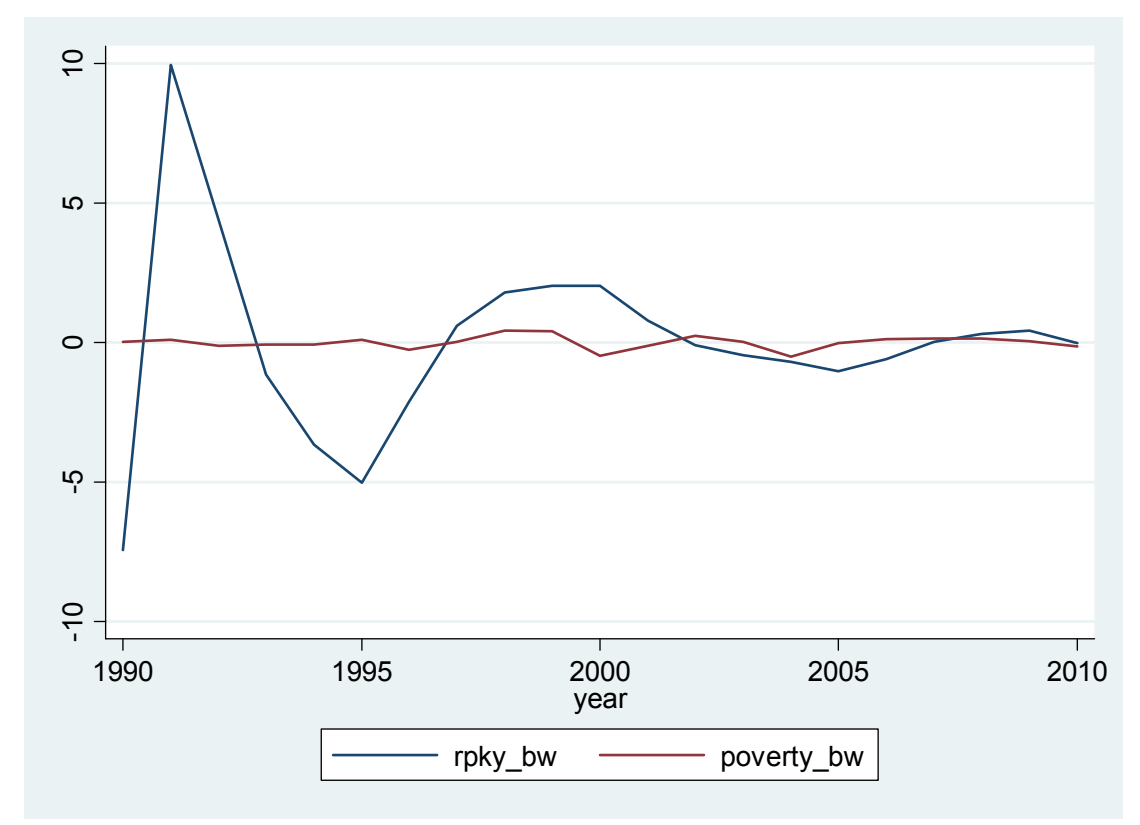

Figure1.

Dynamic Ordinary Least Square (DOLS) method was employed in our estimation. This approach has some advantages over both OLS and maximum likelihood approach (see Stock \& Watson, 1993). First, it has the ability of copying with small and dynamic sources of bias. Johansen technique is a full information technique with common problem that the parameter estimates in one equation are affected if there is misspecification in the others. In the case of DOLS approach, it is different because it is a robust single equation method that corrects for endogeneity using leads and lags of first differences of the regressors in the system, and for serially correlated errors by a Generalised Least Square method. Second, it has equal asymptotic optimality properties as the Johansen distribution. DOLS is useful when the cointegrating coefficient is unknown (Stock, 1987). Also, the method is very simple to implement. In this study, we employ 2 lags and 2 leads.

\section{Discussion of Results and Recommendations}

Annual time series data for 1990-2010 time periods were used for the estimation. The findings of the study show negative relationship between political right and poverty levels, but positive relationship was found when political right was differenced once. The two results were not statistically significant. Usually, most people living in poverty are socially disadvantaged and belong to marginalised groups. Political power and necessary information are necessary when it comes to meaningful participation in political decision-making, thus, our findings support the notion that existence of effective governance will promote accountability, policy solutions and new understanding of poverty reduction among the citizens. The results of this can open up chances of engagement with the state and influence official action that will favour the poor (see Sarelin, 2007; IAG, 2007). However, the statistically insignificant results suggest that the impact of political right on poverty level is minimal in Nigeria. This could then mean that, there is a shortfall in the level of political right in Nigeria.

Political terror was found to reduce poverty with statistically significant result in levels when per capita real income was used for poverty and became positively related with poverty when differenced. This result was statistically significant. This finding is very crucial in the sense that terrorism can force a non-listening government to step up actions that can reduce poverty and at the same time, increased terror can destabilize the economy. Our result supports that of Krueger and Laitin (2003) and Piazza (2004) where they find that terrorism adversely affected economic development. This result suggests that, reduction in political terror is germane to poverty reduction. Also, we find that civil liberty was positively related to poverty, but the result was not statistically significant. Democracy was noted for reducing poverty with statistically significant result, while population increase and poverty were positively related and statistically significant. The results are presented in table 1 below. The negative relation between political terror and poverty may be due to short term government policy intervention, while increased population that are not productive is expected to aggravate poverty. The study recommends productive use of Nigerian population; promote policies that tend to reduce political terror 
and policies that will favour sustainability of democracy.

Table 1. Regression results

\begin{tabular}{|c|c|c|}
\hline & (1) & (2) \\
\hline & poverty_bw & rpky_bw \\
\hline \multirow[t]{2}{*}{ polright } & -0.203 & -1.722 \\
\hline & $(-0.92)$ & $(-1.31)$ \\
\hline \multirow[t]{2}{*}{ D.polright } & 0.219 & 1.373 \\
\hline & $(1.13)$ & $(1.67)$ \\
\hline \multirow[t]{2}{*}{ polterror } & -0.212 & $-7.471 * * *$ \\
\hline & $(-0.90)$ & $(-8.80)$ \\
\hline \multirow[t]{2}{*}{ D.polterror } & -0.0374 & $1.554^{* *}$ \\
\hline & $(-0.20)$ & $(4.58)$ \\
\hline \multirow[t]{2}{*}{ civiliberty } & 0.481 & 1.894 \\
\hline & $(2.10)$ & $(1.03)$ \\
\hline \multirow[t]{2}{*}{ D.civiliberty } & 0.0304 & 1.460 \\
\hline & $(0.28)$ & $(2.18)$ \\
\hline \multirow[t]{2}{*}{ democracy } & $-0.0397 *$ & -0.143 \\
\hline & $(-2.69)$ & $(-1.31)$ \\
\hline \multirow[t]{2}{*}{ D.democracy } & $-0.0242 *$ & -0.120 \\
\hline & $(2.37)$ & $(1.98)$ \\
\hline \multirow[t]{2}{*}{ popincrease } & $0.588^{*}$ & $3.898^{*}$ \\
\hline & $(2.54)$ & $(2.74)$ \\
\hline \multirow[t]{2}{*}{ D.popincrease } & -0.326 & -2.942 \\
\hline & $(-0.50)$ & $(-1.04)$ \\
\hline \multirow[t]{2}{*}{ _cons } & $-14.87^{*}$ & -68.79 \\
\hline & $(-2.67)$ & $(-1.97)$ \\
\hline $\mathrm{N}$ & 18 & 18 \\
\hline \multicolumn{3}{|l|}{$\mathrm{t}$ statistics in parentheses } \\
\hline$* \mathrm{p}<0.05, * * \mathrm{p}<0.01, * * * \mathrm{p}<0.001$ & & \\
\hline
\end{tabular}

\section{References}

Adeyemi, S., Ijaiya, G., \& Raheem, U. (2009). Determinants of Poverty in Sub-Saharan

Africa. An International Multi-Disciplinary Journal, Ethiopia, 3(2), 162-177.

Agénor, P. R. (2005). The macroeconomics of poverty reduction. The Manchester School, 73(4), 369-434. http://dx.doi.org/10.1111/j.1467-9957.2005.00453.x

Akoum, I. F. (2008). Globalization, growth, and poverty: the missing link. International Journal of Social Economics, 35(4), 226-238. http://dx.doi.org/10.1108/03068290810854529

Andersson, M., Engvall, A., \& Kokko, A. (2005). Determinant of Poverty in Lao PDR. Stockholm School of Asian Studies, Working Paper 223.

Apata, T. G., Apata, O. M., Igbalajobi, O. A., \& Awoniyi, S. M. (2010). Determinants of rural poverty in Nigeria: Evidence from small holder farmers in South-western, Nigeria. Journal of Science and Technology Education Research, 1(4), 85-91. 
Azis, I. (2008). Macroeconomic policy and poverty. ADB Institute, ADB Institute Discussion Paper No. 111.

Bianchi, G., \& Sorrentino, R. (2007). Electronic Filter Simulation and Design. New York: McGraw-Hill.

Butterworth, S. (1930). On the theory of filter amplifiers. Experimental Wireless and the Wireless Engineer, 7 , 536-541.

Chirino, J. B., \& Melian, J. M. B. (2006). Analysis of the effectiveness of official Development Assistance. International Research Journal of Finance and Economics, (3).

Christiaensen, L., Demery, L., \& Paternostro, S. (2003). Macro and Micro Perspective of Growth and Poverty in Africa. World Bank, Washington D.C. 20433.

Collier, P., \& Gunning, J. W. (1999). Explaining African Economic Performance. Journal of Economic Literature, 37(1), 64-111. http://dx.doi.org/10.1257/jel.37.1.64

Creedy, J. (1996). Comparing Tax and Transfer Systems: Poverty, Inequality and Target Efficiency. Economica, 63, 163-S174. http://dx.doi.org/10.2307/2554814

Dawood, J., Anwar, C., \& Phillip, E. (2008). An Analysis of Major Determinants of Poverty in Agriculture Sector in Pakistan. Selected Paper for presentation at the American Agricultural Economics Association Annual Meeting, Orlando, FL.

Eirini, V., \& Panos, T. (2011). The Determinants of Poverty Transitions in Europe and the Role of Duration Dependence. IZA Discussion Paper No. 5692.

Epaulard, A. (2003). Macroeconomic performance and poverty reduction. International Monetary Fund, IMF Working PaperNo. 03/72.

European union. (2010). Macro determinants of individual income poverty in 93 regions of Europe. Eurostart Methodogies and Working Papers.

Geda, A., de Jong, N., Kimenyi, M. S., \& Mwabu, G. (2005). Determinants of Poverty in Kenya: A Household Level Analysis. Economics Working Papers.

Hoynes, H. W., Page, M. E., \& Stevens, A. H. (2006). Poverty in America "Trends and Explanations.' Journal of Economic Perspectives, 20, 47-68. http://dx.doi.org/10.1257/089533006776526102

IAG (Inter-Agency Group on Rights Based Approaches). (2007). The Impact of Rights-based Approaches to Development: Evaluation/Learning Process Bangladesh, Malawi and Peru (author S. Crawford). Retrieved from http://www.crin.org/resources/infoDetail.asp?ID=15883

Ibrahim, H., \& Umar, H. S. (2008). Determinants of Poverty among Farming Households in Nasarawa State, Nigeria. Patnsuk Journal, 4(1), 11-21.

Kanbur, R. (2001). Economic Policy, Distribution and Poverty: The Nature of Disagreements. World Development, 29(6), 1083-1094. http://dx.doi.org/10.1016/S0305-750X(01)00017-1

Krueger, A. B., \& Laitin, D. D. (2004). Faulty Terror Report Card. The Washington Post, 17.

Mahbub ul Haq. (1971). Employment and Income Distribution in the 1970's: A new Perspective. Pakistan Economic and Social Review. p. 6.

Masud, N., \& Yontcheva, B. (2005). Does Foreign Aid Reduce Poverty? Empirical Evidence from Nongovernmental and Bilateral Aid. IMF Working Paper 05/100.

Meier, G. M. (1976). Leading Issues in Economic Development (3rd ed.). Oxford University Press, New York.

Morrissey, O. (2004). Conditionality and Aid Effectiveness Re-evaluated. World Economy, 27(2). http://dx.doi.org/10.1111/j.1467-9701.2004.00594.x

Ojimba, T. P. (2012). Socio Demographic Factors as Determinant of poverty in Crude Oil Polluted Crop Farms in River State. International Journal of food and Agricultural Economics, 1(1), 13-25.

Piazza, J. A. (2004). Rooted in Poverty? Terrorism, Poor Economic Development and Social Cleav-ages. Terrorism and Political Violence (forthcoming), 10.

Quisumbing, A. (2007). The Dynamics of Poverty in Rural Bangledesh. CPRC Working Paper No. 105.

Ravallion, M. (2001). Growth, Inequality and Poverty: Looking Beyond Averages. World Development, 29-11.

Rodriguez. (2011). The Determinants of Poverty in the Mexican States of the US-Mexico Border. Puentes Consortium's 2nd Annual Symposium on US-Mexico Border Security. 
Rupasingha, A., \& Goetz, S. (2007). Social and political forces as determinants of poverty: A spatial analysis. Journal of Socio-Economics, 36, 650-671. http://dx.doi.org/10.1016/j.socec.2006.12.021

Sarelin, A. L. (2007). Human rights-based approaches to development cooperation, HIV/AIDS, and food security. Human Rights Quarterly, 29, 460-488. http://dx.doi.org/10.1353/hrq.2007.0022

Sawhill, I. V. (1998). Poverty in the U.S.: Why Is It So Persistent? Journal of Economic Literature, 26, 1073-1119.

Sinnathurai, V., \& Brezinova, O. (2011). Poverty Incidence and its Determinants in the Estate Sector of Sri Lanka. Journal of Competitiveness, 4(1), 44-55.

Stock, J. H. (1987). Asymptotic Properties of Least Squares Estimation of Cointegrating Vectors. Econometrica, 55, 1035-1056. http://dx.doi.org/10.2307/1911260

Stock, J. H., \& Watson, M. W. (1993). A simple estimator of cointegrating vectors in higher order integrated systems. Econometrica, 61(4), 783-820. http://dx.doi.org/10.2307/2951763

Tarabini, A. (2010). Education and Poverty in the global development agenda: Emergence, evolution and consolidation. International Journal of Education Development, 30, 204-212. http://dx.doi.org/10.1016/j.jjedudev.2009.04.009

Tshediso, J.S. (2012). Socio-Economic Determinants of Poverty amongst Female -Headed Households in a South African Township. International Journal of Social Sciences and Humanity Studies, 4(1).

World Bank. (1990). World Development Report, Poverty. New York: Oxford University Press.

World data Bank (World Development Indicators). (2012). Can be found at: http://databank.worldbank.org/ddp/home.do

\section{Copyrights}

Copyright for this article is retained by the author(s), with first publication rights granted to the journal.

This is an open-access article distributed under the terms and conditions of the Creative Commons Attribution license (http://creativecommons.org/licenses/by/3.0/). 